\title{
Evaluation of microbiological safety of commercial spices
}

\author{
Seo-Hyun Lee, Kwang-Ho Mun, Na-Ye-Seul Kim, Jung-Beom Kim* \\ Department of Food science and Technology, Suncheon National University, Suncheon 57922, Korea
}

\section{시중 유통 중인 향신료가공품의 미생물학적 안전성 평가}

\author{
이서현 · 문광호·김나예슬·김중범* \\ 순천대학교 식품공학과
}

\begin{abstract}
The study investigated the level of contamination by total aerobic bacteria, coliform bacteria and food poisoning bacteria in commercial spices for the evaluation of microbiological safety. A total of 119 commercial spices was used for this study. The total aerobic bacterial count was $6.2 \log$ CFU/g in HACCP certificated spices and 5.4 $\log$ CFU/g in HACCP non-certificated spices. Coliform bacteria were detected in 13 (35.1\%) out of 37 HACCP certificated spices and $27(32.9 \%)$ out of 82 HACCP non-certificated spices. Bacillus cereus was detected in 7 (18.9\%) out of 37 HACCP certificated spices and 10 (11.8\%) out of 82 non-certificated spices. All the B. cereus detected in this study possessed at least one toxin gene, and hemolysin BL enterotoxin was detected in 9 (52.9\%) out of $17 \mathrm{~B}$. cereus isolates. Overall, these results indicated that contamination with total aerobic bacteria was higher in HACCP certified spices, with more coliform bacteria and B. cereus detected, than in non-certificated spices. Hence, it is necessary to refine the HACCP system and introduce good agricultural practices for the improvement of microbiological safety of spices.
\end{abstract}

Key words : spices, microbiological safety, HACCP

\section{서 론}

향신료가공품이란 고추(Capsicum annuum), 후추(Piper nigrum), 마늘(Allium sativum), 생강(Zingiber officinale) 등 의 향신식물의 뿌리, 줄기, 열매 등을 단순 가공하거나 식품 또는 식품첨가물을 가하여 가공한 것을 말하며 다른 식품의 풍미를 증진시키기 위해 사용 된다(1). 농림축산통계연보 (2)에 따르면 2016년 건고추, 생강, 마늘의 생산량은 각각 8 만 5천 톤, 5만 9천 톤, 27만 6천 톤으로 고추, 생강, 마늘, 후춧가루가 주요 향신료로 수입, 생산, 소비되고 있다. 고추 는 가지과 다년생으로 남아메리카 열대지역이 원산지이다 (3). 고춧가루는 홍고추를 건조하여 분쇄한 제품으로 김치

*Corresponding author. E-mail : okjbkim@sunchon.ac.kr Phone : 82-61-750-3259, Fax : 82-61-750-3208

Received 14 August 2018; Revised 19 September 2018; Accepted 19 September 2018.

Copyright (c) The Korean Society of Food Preservation. All rights reserved.
와 고추장 제조 시 다량 사용 된다(4). 후추는 후추나무의 열매를 건조시킨 것이 흑후추이며, 흑후추의 껍질을 제거 한 것이 백후추이다(5). 후춧가루는 이를 단순 분쇄 또는 전분 등을 첨가하여 제조하며 육류 등의 누린내를 없애주어 국, 볶음, 구이 등의 식품에 다양하게 사용 된다(5). 생강은 생강과에 속하는 초본식물로 뿌리 특유의 맛.향을 가지고 있어 널리 이용되고(6) 있으며 소화불량, 복통, 설사 등에 효과가 보고되고 있다. 생강가루는 생강을 통째로 분쇄하 거나 전분, 빵가루 등을 첨가하여 제조하며 특유의 매운맛 이 강해 육류의 누린내를 제거하는데 주로 이용된다. 마늘 은 백합과의 식물로 혈압강하, 항암 효과 등의 작용을 가지 고 있으며, 2002년 미국 Time지에 세계 10대 건강식품으로 선정되는 등 기능성 식품원료로 알려져 있다(7-10). 마늘은 특유의 향과 맛으로 음식의 풍미를 좋게 해주어 다양한 요리에 사용 된다(11). 마늘가루는 마늘을 통째 분쇄하거나 전분, 빵가루 등을 첨가하여 제조한다.

고춧가루는 2008년 $\mathrm{HACCP}$ 적용 대상으로 지정되었으 며 2024년까지 의무적용 될 예정이어서 시중 유통되는 대 
부분의 고춧가루는 HACCP 인증제품이다. 그러나 2014년, 2016년, 2017년 식품의약품안전처 검사 결과에 따르면 시 중 유통 중인 고춧가루에서 식중독균이 검출되어 회수조치 되는 등 소비자들의 불안감이 증대되고 있다(12). 고춧가루 를 제외한 향신료 가공품은 현재 $\mathrm{HACCP}$ 적용 대상으로 지정되어 있지 않으며, Park과 Shin(13)의 보고에 따르면 시중 유통 중인 후춧가루에서 $10^{6}-10^{7} \mathrm{CFU} / \mathrm{g}$ 의 일반세균수 가 검출되는 등 위생상 문제점이 제기되고 있어 향신료 가공품의 미생물학적 안전성 평가가 필요하다 하겠다. 그 러나 현재까지 향신료 가공품의 미생물학적 안전성에 대한 연구는 시판 유통 중인 고춧가루의 미생물 및 이화학적 품질 모니터링(14), 유통 건고추 및 고춧가루의 아플라톡신 $\mathrm{B} 1$ 과 오크라톡신 A 오염도 조사(15), 고춧가루의 $\mathrm{HACCP}$ 시스템 적용을 위한 미생물학적 위해분석(16), 적외선살균 이 고춧가루의 품질에 미치는 영향(17), 국내 유통 고춧가루 의 병원성 대장균 오염 및 대장균 저감화 방법(18), 시중 판매 후추의 오염도 및 회분식 광펄스 처리에 의한 살균 효과(13) 등 시중 유통 중인 고춧가루의 미생물학적, 이화학 적 안전성에 한정되어 있고 다소비 향신료가공품의 미생물 학적 안전성 연구는 전무한 실정이다. 따라서 본 연구에서 는 대표적인 향신료가공품인 고춧가루, 후춧가루, 생강가 루, 마늘가루의 일반세균, 대장균군 및 식중독균 오염도를 평가하고자 하였다.

\section{재료 및 방법}

\section{실험재료}

본 실험에 사용된 재료는 시중 유통 중인 고춧가루 45건, 후춧가루 28 건, 생강가루 29 건, 마늘가루 17 건, 총 119 건의 향신료를 사용하였다. HACCP 인증 유무에 따라 향신료를 구분하면 HACCP 인증제품 37건, HACCP 미인증제품 82건 이었으며, 원산지에 따라 구분하면 국내산이 54건, 수입산 이 65 건이었다.

\section{시료 전처리}

시료 $25 \mathrm{~g}$ 을 정밀히 달아 멸균인산완충희석액 $225 \mathrm{~mL}$ 를 가하여 균질기(BagMixer ${ }^{\circledR} 400$, Interscience, St Nom, France)로 60 초간 균질화하여 시험 원액으로 하였다. 시험 원액을 10 단계 계단 희석하여 시험용액으로 하였다.

\section{일반세균 및 대장균군}

일반세균 및 대장균군 정량 실험은 식품공전(1)에 따라 실험하였다. Sanita-kun 건조필름(Chisso Corp., Tokyo, Japan)에 각각의 시험 용액 $1 \mathrm{~mL}$ 를 분주하고, 일반세균은 $35^{\circ} \mathrm{C}$ 배양기(Daewon, DS-110M, Bucheon, Korea)에서 48 시간 배양하여 생성된 붉은색 집락을 계수해 측정하였으
며, 대장균군은 $35^{\circ} \mathrm{C}$ 에서 24 시간 배양하여 생성된 푸른색 집락을 계수하였다.

\section{식중독 세균 실험}

식중독세균은 시험원액 $1 \mathrm{~mL}$ 를 tryptic soy broth(TSB; Oxoid, London, England) $10 \mathrm{~mL}$ 에 접종한 후 $35^{\circ} \mathrm{C}, 24$ 시간 배양하였다. 배양된 균액을 eppendorf tube에 $1 \mathrm{~mL}$ 취한 후 원심분리기(Smart R17, Hanil scientific, Gimpo, Korea)를 이용하여 $12,000 \mathrm{rpm}, 10$ 분간 원심분리하였다. 원심분리 후 상층액을 제거하고 멸균증류수 $1 \mathrm{~mL}$ 를 가하여 12,000 $\mathrm{rpm}$ 에서 10 분간 원심분리하였다. 이 과정을 3 회 반복한 후 eppendorf tube에 멸균증류수 $1 \mathrm{~mL}$ 를 가하여 $99^{\circ} \mathrm{C}$ Heating block(HB-96D, set, Daihan scientific, Wonju, Korea) 에서 10 분간 가열하였다. 가열 후 $12,000 \mathrm{rpm}$ 에서 10 분간 원심분리 하여 상층액을 polymerase chain reaction(PCR) 주형 DNA로 사용하였다. 식중독균은 Multiplex Pathogen Detection Kit(Kogenbiotech, Seoul, Korea)를 이용하여 확인 하였다. PCR 조건은 $95^{\circ} \mathrm{C}, 10 \mathrm{~min} \rightarrow\left(95^{\circ} \mathrm{C}, 35 \mathrm{sec} \rightarrow 60^{\circ} \mathrm{C}\right.$, $\left.30 \mathrm{sec} \rightarrow 72^{\circ} \mathrm{C} 30 \mathrm{sec}\right) 35 \mathrm{cycle} \rightarrow 72^{\circ} \mathrm{C}, 10 \mathrm{~min}$ 으로 실험하였 다. 식중독균의 특이유전자를 확인하기 위하여 $2 \%$ 아가로 즈 겔 상에 증폭시킨 PCR product $5 \mu \mathrm{L}$ 를 로딩 하여 110 $\mathrm{V}$ 에서 50 분간 전기영동을 실시하였다. 전기영동 후 $\mathrm{UV}$ trasilluminator(Biomics, Daejeon, Korea)를 이용하여 Salmonella spp., Listeria monocytogenes, Bacillus cereus, E. coli O157, Yersinia enterocolitica, Vibrio parahaemolyticus, Staphylococcus aureus 등 7종의 식중독균 특이유전자 밴드 를 확인하였다.

\section{Bacillus cereus 분리 동정}

$\mathrm{PCR}$ 을 이용한 식중독 세균 실험에서 B. cereus 밴드가 확인된 시료를 식품공전 B. cereus 정성시험에 따라 mannitol egg yolk polymyxin agar(MYP; Oxiod)배지를 이용하여 실 험하였다. 시험 용액 $200 \mu \mathrm{L}$ 를 MYP배지에 spreading한 후 $30^{\circ} \mathrm{C}$ 배양기에서 24 시간 배양하여 혼탁한 환을 갖는 분홍색 집락을 확인하였다. MYP 배지에서 전형적인 집락이 확인 된 균주를 tryptic soy agar(TSA; Oxoid)에 접종하여 $35^{\circ} \mathrm{C}$, 24시간 배양한 후 API $50 \mathrm{CHB}$ 또는 Vitek BCL(bioMérieux, Inc., Marcy 1'Etoile, France)을 이용하여 동정하였다.

\section{Bacillus cereus 독소유전자 및 독소단백질}

독소 유전자는 식중독 세균 실험에서 사용한 $\mathrm{DNA}$ 를 이 용하였다. 각각의 독소유전자 $\operatorname{primer}(n h e A, n h e B, n h e C$, $h b l C, h b l D, h b l A$, entFM) $8 \mu \mathrm{L}$, 추출 DNA $4 \mu \mathrm{L}$, 증류수 $8 \mu \mathrm{L}$ 를 PCR primix(Bioneer, Daejeon, Korea) tube에 분주하 였으며 각각 primer sequence는 Table 1에 나타내었다. PCR 반응은 $95^{\circ} \mathrm{C}, 30 \mathrm{sec} \rightarrow\left(95^{\circ} \mathrm{C}, 30 \mathrm{sec} \rightarrow 60^{\circ} \mathrm{C}, 1 \mathrm{~min} \rightarrow 72^{\circ} \mathrm{C} 1\right.$ $\min ) 35 \mathrm{cycle} \rightarrow 72^{\circ} \mathrm{C}, 5 \mathrm{~min}$ 으로 실험하였다. $\mathrm{DNA}$ 를 증폭한 
Table 1. Primer sequences and reaction conditions for the detection of enterotoxin gens

\begin{tabular}{|c|c|c|c|c|}
\hline Target gene & Primers & $\begin{array}{l}\text { Products } \\
\text { size(bp) }\end{array}$ & Sequence $\left(5^{\prime}-3^{\prime}\right)$ & Reference \\
\hline$h b l A$ & $\begin{array}{l}\text { FhblA } \\
\text { RhblA }\end{array}$ & 884 & $\begin{array}{l}\text { GCA AAA TCT ATG AAT GCC TA } \\
\text { GCA TCT GTT CGT AAT GTT TT }\end{array}$ & \multirow{3}{*}{ (30) } \\
\hline$h b l C$ & $\begin{array}{l}\text { FhblC } \\
\text { RhblC }\end{array}$ & 695 & $\begin{array}{l}\text { CCT ATC AAT ACT CTC GCA A } \\
\text { TTT CCT TTG TTA TAC GCT GC }\end{array}$ & \\
\hline$h b I D$ & $\begin{array}{l}\text { FhblD } \\
\text { RhblD }\end{array}$ & 1018 & $\begin{array}{l}\text { GAA ACA GGG TCT CAT ATT CT } \\
\text { CTG CAT CTT TAT GAA TAT CA }\end{array}$ & \\
\hline nheA & $\begin{array}{l}\text { NA-F1 } \\
\text { NA-R1 }\end{array}$ & 475 & $\begin{array}{l}\text { ATT ACA GGG TTA TTG GTT ACA GCA GT } \\
\text { AAT CTT GCT CCA TACT CT CTT GGA TGC T }\end{array}$ & \multirow{3}{*}{ (31) } \\
\hline nheB & $\begin{array}{l}\text { NB-F1 } \\
\text { NB-R1 }\end{array}$ & 328 & $\begin{array}{l}\text { GTA CAG CAG CTG TAG GCG GT } \\
\text { ATG TTT TTC CAG CTA TCT TTC GCA AT }\end{array}$ & \\
\hline nheC & $\begin{array}{l}\text { NC-F1 } \\
\text { NC-R2 }\end{array}$ & 557 & $\begin{array}{l}\text { GCG GAT ATT GTA AAG AAT CAA AAT GAG GT } \\
\text { TTT CCA GCT ATC TTT CGC TGT ATG TAA AT }\end{array}$ & \\
\hline entFM & $\begin{array}{l}\text { ENTFMF } \\
\text { ENTFMR }\end{array}$ & 596 & $\begin{array}{l}\text { AAA GAA ATT AAT GGA CAA ACT CAA ACT CA } \\
\text { GTA TGT AGC TGG GCC TGT ACG T }\end{array}$ & (32) \\
\hline
\end{tabular}

후 독소 유전자를 확인하기 위하여 $2 \%$ 아가로즈 겔 상에 $\mathrm{PCR}$ product $5 \mu \mathrm{L}$ 로딩 후 $110 \mathrm{~V}$ 에서 50 분간 전기영동 하였다. 전기영동 결과 밴드 형성 여부를 확인하여 독소 유전자 유무를 판정하였다.

독소단백질 확인을 위해 시험원액 $1 \mathrm{~mL}$ 를 tryptic soy broth(TSB; Oxoid) $10 \mathrm{~mL}$ 에 접종 한 후 $35^{\circ} \mathrm{C}, 24$ 시간 배양하 였다. 배양액을 $12,000 \mathrm{mpm}, 10$ 분간 원심분리한 후 상층액 을 독소단백질 실험에 사용하였다. B. cereus가 생산하는 대표적인 독소단백질인 Hemolysin BL enterotoxin(HBL) 생 산능은 B. cereus Enterotoxin-Reversed Passive Latex Agglutination kit(BCET-RPLA; Oxoid)를 사용하여 제조사 가 제시하는 방법에 따라 실시하였다.

\section{통계처리}

통계처리는 SPSS V17.0(SPSS Inc, Chicago, IL, USA) 통계처리 프로그램을 이용하였다. 독립표본 t-test로 두 집 단 간의 평균값을 비교하였으며 유의수준 $\mathrm{p}<0.05$ 로 각각 향신료의 일반세균수와 대장균군수의 유의적 차이를 검증 하였다.

\section{결과 및 고찰}

\section{일반세균 오염 현황}

본 실험에 사용된 향신료는 Table 2에 나타내었으며 $\mathrm{HACCP}$ 인증 여부와 원산지에 따라 분류하였다. 고춧가루 는 45 개 중 35 개 제품이 $\mathrm{HACCP}$ 인증, 10 개 제품이 $\mathrm{HACCP}$ 미인증 제품이었으며, 31 개 제품은 국내산, 14 개 제품은 중국 등 수입 제품이었다. 후춧가루는 28 개 제품 중 2 개 제품이 $\mathrm{HACCP}$ 인증, 26 개 제품이 $\mathrm{HACCP}$ 미인증 제품이 었으며, 28 개 제품 모두가 인도네시아 등 수입 제품이었다.
생강가루는 29개 제품 모두 HACCP 미인증 제품이었으며 15 개 제품은 국내산, 14 개 제품은 수입 제품이었다. 마늘가 루는 17 개 제품 모두 $\mathrm{HACCP}$ 미인증 제품이었으며 7 개 제품은 국내산, 10 개 제품은 수입 제품이었다.

$\mathrm{HACCP}$ 인증 여부와 원산지에 따른 향신료의 일반세균 정량시험 결과는 Table 3에 나타내었다. $\mathrm{HACCP}$ 인증 여부 에 따른 고춧가루 일반세균 오염도는 $\mathrm{HACCP}$ 인증 제품의 경우 $6.5 \pm 0.6 \log \mathrm{CFU} / \mathrm{g}, \mathrm{HACCP}$ 미인증 제품의 경우 $6.2 \pm 0.8 \log \mathrm{CFU} / \mathrm{g}$ 으로 유의적 차이가 나타나지 않았다. 후춧가루는 $\mathrm{HACCP}$ 인증 제품에서 평균 $2.2 \pm 1.3 \log \mathrm{CFU} / \mathrm{g}$, $\mathrm{HACCP}$ 미인증 제품에서 평균 $4.8 \pm 2.3 \log \mathrm{CFU} / \mathrm{g}$ 으로 $\mathrm{HACCP}$ 미인증 제품이 높은 오염도를 나타내었다. 생강가 루, 마늘가루는 모두 $\mathrm{HACCP}$ 미인증 제품이었으며 각각 $6.0 \pm 1.7 \log \mathrm{CFU} / \mathrm{g}, 5.0 \pm 0.8 \log \mathrm{CFU} / \mathrm{g}$ 의 오염도를 나타내었 다. 전체적인 향신료의 일반세균 오염도는 $\mathrm{HACCP}$ 인증 제품에서 평균 $6.2 \pm 1.2 \log \mathrm{CFU} / \mathrm{g}$ 으로 나타났으며 $\mathrm{HACCP}$ 미인증 제품은 평균 $5.4 \pm 1.8 \log \mathrm{CFU} / \mathrm{g}$ 으로 $\mathrm{HACCP}$ 인증 제품이 약간 높은 오염도를 나타내었으나 HACCP 인증 유무에 따른 일반세균수는 유의적인 차이는 나타나지 않았 다.

원산지에 따른 향신료의 일반세균 오염도는 국내산 고춧 가루에서 평균 $6.5 \pm 0.7 \log \mathrm{CFU} / \mathrm{g}$, 수입산 고춧가루에서 평균 $6.2 \pm 0.5 \log \mathrm{CFU} / \mathrm{g}$ 으로 유의적인 차이가 나타나지 않 았다. 후춧가루는 모두 수입제품이었으며 평균 $4.6 \pm 2.3 \mathrm{log}$ $\mathrm{CFU} / \mathrm{g}$ 으로 나타났다. 생강가루는 국내산이 평균 $6.5 \pm 1.9$ $\log \mathrm{CFU} / \mathrm{g}$, 수입산이 평균 $5.4 \pm 1.4 \log \mathrm{CFU} / \mathrm{g}$ 으로 나타났으 나 유의적 차이가 나타나지 않았다. 마늘가루는 국내산이 평균 $5.2 \pm 0.8 \log \mathrm{CFU} / \mathrm{g}$, 수입산이 평균 $4.8 \pm 0.9 \log \mathrm{CFU} / \mathrm{g}$ 으로 유의적 차이가 나타나지 않았다. 전체적인 향신료의 일반세균 오염도는 국내산 제품이 평균 $6.3 \pm 1.2 \log \mathrm{CFU} / \mathrm{g}$ 으로 나타났으며 수입산은 평균 $5.1 \pm 1.8 \mathrm{log} \mathrm{CFU} / \mathrm{g}$ 으로 나 
Table 2. Classification of spice samples

\begin{tabular}{cccccc}
\hline \multirow{2}{*}{ Sample name } & \multirow{2}{*}{ Number of samples } & \multicolumn{2}{c}{ HACCP certification } & \multicolumn{2}{c}{ Region } \\
\cline { 3 - 6 } & & Certification & Non certification & Domestics & Imported \\
\hline Red pepper powder & 45 & 35 & 10 & 32 & 13 \\
Pepper powder & 28 & 2 & 26 & - & 28 \\
Ginger powder & 29 & - & 29 & 15 & 14 \\
Garlic powder & 17 & - & 17 & 47 & 10 \\
\hline Total & 102 & 37 & 65 & 55 \\
\hline
\end{tabular}

Table 3. Detection rate (\%) of total aerobic bacteria in spice samples

\begin{tabular}{|c|c|c|c|c|c|c|}
\hline \multirow[b]{2}{*}{ Sample name } & \multicolumn{3}{|c|}{ HACCP } & \multicolumn{3}{|c|}{ Region } \\
\hline & HACCP certification & $\begin{array}{l}\text { Number of detection } \\
\text { samples }\end{array}$ & Mean $(\log \mathrm{CFU} / \mathrm{g})$ & Region & $\begin{array}{l}\text { Number of detection } \\
\text { samples }\end{array}$ & Mean $(\log \mathrm{CFU} / \mathrm{g})$ \\
\hline \multirow{3}{*}{ Red pepper powder } & HACCP $(n=35)$ & $35(100.0 \%)$ & $6.5 \pm 0.6^{\text {al) }}$ & Domestics (n=31) & $31(100.0 \%)$ & $6.5 \pm 0.7^{\mathrm{a}}$ \\
\hline & Non-HACCP (n=10) & $10(100.0 \%)$ & $6.2 \pm 0.8^{\mathrm{a}}$ & Imported (n=14) & $14(100.0 \%)$ & $6.2 \pm 0.5^{\mathrm{a}}$ \\
\hline & Total $(n=45)$ & $45(100.0 \%)$ & $6.4 \pm 0.7$ & Total $(n=45)$ & $45(100.0 \%)$ & $6.4 \pm 0.7$ \\
\hline \multirow{3}{*}{ Pepper powder } & HACCP $(n=2)$ & $2(100.0 \%)$ & $2.2 \pm 1.3^{\mathrm{b}}$ & Domestics $(\mathrm{n}=0)$ & - & - \\
\hline & Non-HACCP (n=26) & $26(100 \%)$ & $4.8 \pm 2.3^{\mathrm{c}}$ & Imported (n=28) & $28(100 \%)$ & $4.6 \pm 2.3$ \\
\hline & Total $(\mathrm{n}=28)$ & $28(100 \%)$ & $4.6 \pm 2.3$ & Total $(\mathrm{n}=28)$ & $28(100 \%)$ & $4.6 \pm 2.3$ \\
\hline \multirow{3}{*}{ Ginger powder } & HACCP $(n=0)$ & - & - & Domestics $(n=15)$ & $15(100 \%)$ & $6.5 \pm 1.9^{\mathrm{b}}$ \\
\hline & Non-HACCP (n=29) & $29(100 \%)$ & $6.0 \pm 1.7$ & Imported (n=14) & $14(100.0 \%)$ & $5.4 \pm 1.4^{\mathrm{b}}$ \\
\hline & Total $(\mathrm{n}=29)$ & $29(100 \%)$ & $6.0 \pm 1.7$ & Total $(\mathrm{n}=29)$ & $29(100 \%)$ & $6.0 \pm 1.7$ \\
\hline \multirow{3}{*}{ Garlic powder } & HACCP $(n=0)$ & - & - & Domestics $(\mathrm{n}=7)$ & $7(100.0 \%)$ & $5.2 \pm 0.8^{c}$ \\
\hline & Non-HACCP (n=17) & $17(100.0 \%)$ & $5.0 \pm 0.8$ & Imported $(\mathrm{n}=10)$ & $10(100.0 \%)$ & $4.8 \pm 0.9^{c}$ \\
\hline & Total $(n=17)$ & $17(100.0 \%)$ & $5.0 \pm 0.8$ & Total $(n=17)$ & $17(100.0 \%)$ & $5.0 \pm 0.8$ \\
\hline \multirow{3}{*}{ Total } & HACCP $(n=37)$ & $37(100.0 \%)$ & $6.2 \pm 1.2^{\mathrm{d}}$ & Domestics $(\mathrm{n}=55)$ & $55(100 \%)$ & $6.3 \pm 1.2^{\mathrm{d}}$ \\
\hline & Non-HACCP (n=82) & $82(100 \%)$ & $5.4 \pm 1.8^{\mathrm{d}}$ & Imported (n=67) & $67(100 \%)$ & $5.1 \pm 1.8^{\mathrm{e}}$ \\
\hline & Total $(\mathrm{n}=119)$ & $119(100 \%)$ & $5.7 \pm 1.7$ & Total $(\mathrm{n}=119)$ & $119(100 \%)$ & $5.7 \pm 1.7$ \\
\hline
\end{tabular}

${ }^{1)}$ Different superscripts are significantly different at $p<0.05$.

타나 국내산 제품이 수입산보다 높은 오염도를 나타내었 다.

고춧가루의 일반세균 오염도는 HACCP 인증 여부, 원산 지와 무관하게 모두 $6.0 \log \mathrm{CFU} / \mathrm{g}$ 이상으로 높은 수치를 나타내었으며 이러한 결과는 Jeong 등(17)의 적외선 살균 전 고춧가루 일반세균수 오염도가 $6.1 \log \mathrm{CFU} / \mathrm{g}$ 였다는 보고와 유사하였고, Park 등(16)의 적외선 살균 전 고춧가루 일반세균수 오염도가 $5.0 \log \mathrm{CFU} / \mathrm{g}$, Woo 등의 연구결과 (19) $5.1 \log \mathrm{CFU} / \mathrm{g}$ 보다 다소 높게 나타났다. 이는 Solberg 등(20)이 제시한 조리되지 않은 식품의 미생물 판정 기준인 $6.0 \log \mathrm{CFU} / \mathrm{g}$ 이상으로 면역기능이 약한 사람에게 식중독 을 일으킬 가능성이 있을 것으로 판단된다(21). HACCP 인증을 받은 고춧가루는 제조 공정 중 자외선을 이용하여 미생물을 살균하고 있으며 Park 등(16)의 연구결과 고춧가 루의 자외선 살균 후 일반세균은 $5.0 \log \mathrm{CFU} / \mathrm{g}$ 에서 3.9 $\log \mathrm{CFU} / \mathrm{g}$ 까지 감소하였다고 보고하였다. 본 실험 결과 $\mathrm{HACCP}$ 인증 고춧가루의 일반세균수 오염도는 $6.4 \pm 0.6 \mathrm{log}$ $\mathrm{CFU} / \mathrm{g}$ 으로 나타나 자외선 살균공정 등 고춧가루 제조 $\mathrm{HACCP}$ 시스템에 대한 종합적인 점검과 보완이 필요한 것으로 판단된다. 본 실험에 사용된 후춧가루는 모두 수입 산이었으며, 일반세균수 오염도는 Mok 등(22)의 연구결과 인 $3.0 \log \mathrm{CFU} / \mathrm{g}$ 보다 높게 나타났다. HACCP 인증 유무에 따른 일반세균수 오염도는 $\mathrm{HACCP}$ 인증 제품이 HACCP 미인증 제품에 비하여 $2.6 \log \mathrm{CFU} / \mathrm{g}$ 낮아 후춧가루 제조 공정에 $\mathrm{HACCP}$ 시스템 도입 확대가 필요한 것으로 판단된 다. 시중 유통 중인 생강가루와 마늘가루는 HACCP 인증 제품이 없었으며, $5.0 \log \mathrm{CFU/g}$ 이상으로 높은 일반세균수 가 검출되어 적절한 위생관리 시스템의 도입이 필요한 것으 로 판단된다. 


\section{대장균군 오염 현황}

HACCP 인증 여부와 원산지에 따른 향신료의 대장균군 정량시험 결과는 Table 4에 나타내었다. 고춧가루는 $\mathrm{HACCP}$ 인증 제품에서 대장균군이 $37.1 \%$ 검출되었으며, $\mathrm{HACCP}$ 미인증 제품에서 $30.0 \%$ 검출되어 $\mathrm{HACCP}$ 인증 제품에서 더 높은 대장균군 검출률이 나타났다. 후춧가루 는 $\mathrm{HACCP}$ 인증 제품에서 대장균군이 검출되지 않았으며, $\mathrm{HACCP}$ 미인증 제품에서 검출률 $38.5 \%$ 로 나타났다. 생강 가루와 마늘가루는 모두 HACCP 미인증 제품이었으며 생 강가루의 검출률은 $48.3 \%$ 로 나타났으며, 마늘가루에서는 대장균군이 검출되지 않았다. 전체적인 향신료의 대장균군 오염도는 $\mathrm{HACCP}$ 인증 제품에서 검출률 $35.1 \%, \mathrm{HACCP}$ 미인증 제품에서 검출률 $32.9 \%$ 로 $\mathrm{HACCP}$ 인증 제품에서 약간 높은 검출률을 나타내었다.

원산지에 따른 대장균군 오염도는 국내산 고춧가루에서 검출률 $45.2 \%$, 수입산 고춧가루에서 검출률 $14.3 \%$ 로 국내 산 제품에서 더 높은 검출률을 나타내었다. 후춧가루는 모 두 수입제품이었으며 검출률 $35.7 \%$ 로 나타났다. 생강가루 는 국내산이 검출률 $60.0 \%$, 수입산이 검출률 $35.7 \%$ 로 나타 나 국내산 제품에서 더 높은 검출률이 나타났다. 전체적인 향신료의 대장균군 오염도는 국내산 제품에서 검출률 $41.8 \%$, 수입산 제품에서 검출률 $25.4 \%$ 로 국내산 제품에서 더 높은 대장균군 검출률을 나타내었다.

본 실험 결과 고춧가루 대장균군 오염도는 Woo 등(19)의 연구결과인 $1.5 \log \mathrm{CFU} / \mathrm{g}$, Lee 등(23)의 연구결과인 3.4 $\log \mathrm{CFU} / \mathrm{g}$, Kwon 등(24)의 연구결과인 $4.3 \log \mathrm{CFU} / \mathrm{g}$ 보다 낮은 오염도를 나타내었으나, 대장균군 검출률이 $35.6 \%$ 로 위생상 문제점을 내포하고 있었다. 후춧가루와 생강가루는
대장균군 검출 보고가 매우 미약하여 본 실험 결과와 직접 적으로 비교하지 못하였으나, 대장균군 검출률이 각각 $35.7 \%, 48.3 \%$ 로 나타나 위생상 문제점을 나타내었다. 마늘 가루는 마늘의 alicin 성분이 대장균에 항균 작용을 가진다 는 연구결과(25)로 보아 마늘의 항균 작용에 의하여 대장균 군이 검출되지 않은 것으로 판단된다. 향신료의 전체적인 대장균군 오염도는 $\mathrm{HACCP}$ 인증여부, 원산지와 관계없이 높게 나타나 적절한 위생관리 시스템의 도입과 함께 생산단 계부터 농산물의 대장균군 오염을 관리할 수 있는 농산물우 수관리 제도(good agricultural practice; GAP) 도입이 필요할 것으로 판단된다.

\section{식중독 세균 오염 현황}

향신료의 식중독세균 실험결과는 Table 5에 나타내었으 며 119 건의 향신료 중 17 건(13.9\%)에서 B. cereus가 검출되 었으며 L. monocytogenes, E. coli O157, Y. enterocolitica, V. parahaemolyticus, Staph. aureus, Salmonella spp. 등의 식중독 세균은 검출되지 않았다. 고춧가루 $22.2 \%$ 에서 $B$. cereus가 검출되었으며 $\mathrm{HACCP}$ 인증 제품에서 $20 \%$, $\mathrm{HACCP}$ 미인증 제품에서 $30 \%$ 검출되어 $\mathrm{HACCP}$ 미인증 제품의 B. cereus 오염도가 높은 것으로 확인되었다. 고춧가 루 중 B. cereus 오염도를 원산지별로 구분해보면 국내산이 $21.9 \%$, 수입산이 $23.9 \%$ 검출되어 원산지별 차이는 나타나 지 않았다. 후춧가루의 경우 $13.3 \%$ 에서 B. cereus가 검출되 었으며 모두 HACCP 미인증 제품에서 검출되었고 수입산 이었다. 생강가루의 경우 $10.0 \%$ 에서 B. cereus가 검출되었 으며 모두 $\mathrm{HACCP}$ 미인증 제품이며, 원산지로 구분하면 국내산 $12.5 \%$, 수입산 $7.1 \%$ 로 국내산 제품의 B. cereus 오염 도가 더 높게 나타났다.

Table 4. Detection rate (\%) of coliform in spice samples

\begin{tabular}{|c|c|c|c|c|c|c|}
\hline \multirow[b]{2}{*}{ Sample name } & \multicolumn{3}{|c|}{ HACCP } & \multicolumn{3}{|c|}{ Region } \\
\hline & HACCP certification & $\begin{array}{l}\text { Number of detection } \\
\text { samples }\end{array}$ & Mean $(\log \mathrm{CFU} / \mathrm{g})$ & Region & $\begin{array}{l}\text { Number of detection } \\
\text { samples }\end{array}$ & Mean (log CFU/g) \\
\hline \multirow{3}{*}{ Red pepper powder } & HACCP (n=35) & $13(37.1 \%)$ & $1.1 \pm 1.4^{\mathrm{a}}$ & Domestics $(\mathrm{n}=31)$ & $14(45.2 \%)$ & $1.3 \pm 1.5^{\mathrm{a}}$ \\
\hline & Non-HACCP $(n=10)$ & $3(30.0 \%)$ & $0.8 \pm 1.3^{\mathrm{a}}$ & Imported $(n=14)$ & $2(14.3 \%)$ & $0.4 \pm 11^{\mathrm{a}}$ \\
\hline & Total $(n=45)$ & $16(35.6 \%)$ & $1.0 \pm 1.4$ & Total $(n=45)$ & $16(35.6 \%)$ & $1.0 \pm 1.4$ \\
\hline \multirow{3}{*}{ Pepper powder } & HACCP $(\mathrm{n}=2)$ & $0(0.0)$ & - & Domestics $(\mathrm{n}=0)$ & - & - \\
\hline & Non-HACCP $(\mathrm{n}=26)$ & $10(38.5 \%)$ & $1.0 \pm 1.4$ & Imported $(\mathrm{n}=28)$ & $10(35.7 \%)$ & $0.9 \pm 1.4$ \\
\hline & Total $(n=28)$ & $10(35.7 \%)$ & $0.9 \pm 1.4$ & Total $(n=28)$ & $10(35.7 \%)$ & $0.9 \pm 1.4$ \\
\hline \multirow{3}{*}{ Ginger powder } & HACCP $(n=0)$ & - & - & Domestics $(n=15)$ & $9(60.0 \%)$ & $2.6 \pm 2.8^{\mathrm{b}}$ \\
\hline & Non-HACCP (n=29) & $14(48.3 \%)$ & $2.0 \pm 2.5$ & Imported (n=14) & $5(35.7 \%)$ & $1.3 \pm 2.1^{\mathrm{b}}$ \\
\hline & Total $(n=29)$ & $14(48.3 \%)$ & $2.0 \pm 2.5$ & Total $(\mathrm{n}=29)$ & $14(48.3 \%)$ & $2.0 \pm 2.5$ \\
\hline \multirow{3}{*}{ Total } & HACCP $(n=37)$ & $13(35.1 \%)$ & $1.0 \pm 1.4^{\mathrm{b}}$ & Domestics $(\mathrm{n}=55)$ & $23(41.8 \%)$ & $1.5 \pm 2.0^{\mathrm{c}}$ \\
\hline & Non-HACCP $(\mathrm{n}=82)$ & $27(32.9 \%)$ & $1.1 \pm 1.9^{\mathrm{b}}$ & Imported (n=67) & $17(25.4 \%)$ & $0.8 \pm 1.5^{\mathrm{c}}$ \\
\hline & Total $(n=119)$ & $40(33.6 \%)$ & $1.1 \pm 1.7$ & Total $(\mathrm{n}=119)$ & $40(33.6 \%)$ & $1.1 \pm 1.7$ \\
\hline
\end{tabular}

${ }^{1)}$ Different superscripts are significantly different at $\mathrm{p}<0.05$. 
Table 5. Detection rate (\%) of Bacillus cereus in spice samples

\begin{tabular}{|c|c|c|c|c|}
\hline \multirow{2}{*}{ Sample name } & \multicolumn{2}{|c|}{ НАCCP } & \multicolumn{2}{|c|}{ Region } \\
\hline & HACCP certification & Number of detection samples & Region & Number of detection samples \\
\hline \multirow{3}{*}{ Red pepper powder } & HACCP (n=35) & $7(20.0 \%)$ & Domestics ( $\mathrm{n}=32)$ & $7(21.9 \%)$ \\
\hline & Non-HACCP (n=10) & $3(30.0 \%)$ & Imported (n=13) & $3(23.9 \%)$ \\
\hline & Total $(n=45)$ & $10(22.2 \%)$ & Total $(\mathrm{n}=45)$ & $10(22.2 \%)$ \\
\hline \multirow{3}{*}{ Pepper powder } & $\mathrm{HACCP}(\mathrm{n}=2)$ & - & Domestics $(\mathrm{n}=0)$ & - \\
\hline & Non-HACCP (n=26) & $4(14.3 \%)$ & Imported (n=28) & $4(13.3 \%)$ \\
\hline & Total $(\mathrm{n}=28)$ & $4(13.3 \%)$ & Total $(\mathrm{n}=28)$ & $4(13.3 \%)$ \\
\hline \multirow{3}{*}{ Ginger powder } & HACCP $(\mathrm{n}=0)$ & - & Domestics (n=15) & $2(12.5 \%)$ \\
\hline & Non-HACCP (n=29) & $3(10.0 \%)$ & Imported (n=14) & $1(7.1 \%)$ \\
\hline & Total $(\mathrm{n}=29)$ & $3(10.0 \%)$ & Total $(\mathrm{n}=29)$ & $3(10.0 \%)$ \\
\hline \multirow{3}{*}{ Garlic powder } & HACCP $(\mathrm{n}=0)$ & - & Domestics (n=7) & - \\
\hline & Non-HACCP (n=17) & - & Imported (n=10) & - \\
\hline & Total $(\mathrm{n}=30)$ & & Total $(\mathrm{n}=17)$ & \\
\hline \multirow{3}{*}{ Total } & HACCP $(n=37)$ & $7(18.9 \%)$ & Domestics ( $\mathrm{n}=55$ ) & $9(16.7 \%)$ \\
\hline & Non-HACCP (n=82) & $10(11.8 \%)$ & Imported $(\mathrm{n}=67)$ & $8(11.9 \%)$ \\
\hline & Total $(n=119)$ & $17(13.9 \%)$ & Total $(n=119)$ & 17 (13.9\%) \\
\hline
\end{tabular}

Table 6. Detection of toxin genes and toxin protein in Bacillus cereus isolated from red pepper powder, pepper powder, ginger powder

\begin{tabular}{|c|c|c|c|c|c|c|c|c|}
\hline \multirow{2}{*}{ Sample } & \multicolumn{7}{|c|}{ Toxin gene } & \multirow{2}{*}{$\begin{array}{c}\text { Toxin protein } \\
\text { HBL enterotoxin }\end{array}$} \\
\hline & nheA & nheB & nheC & $h b l C$ & $h b I D$ & $h b l A$ & entFM & \\
\hline $\mathrm{R} 4$ & + & + & + & & & & + & \\
\hline R5 & + & + & + & & & & + & \\
\hline R10 & + & + & + & + & + & + & + & + \\
\hline R29 & + & + & + & + & + & + & + & + \\
\hline R30 & & + & + & + & + & + & + & + \\
\hline $\mathrm{R} 33$ & + & + & + & + & + & + & + & + \\
\hline R34 & + & + & + & + & + & + & + & + \\
\hline R39 & + & + & + & + & + & + & + & + \\
\hline $\mathrm{R} 40$ & + & + & + & & & & + & \\
\hline R45 & + & + & + & & & & + & \\
\hline $\mathrm{P} 12$ & + & + & + & & & & + & \\
\hline P15 & + & + & + & & & & + & \\
\hline $\mathrm{P} 20$ & + & + & + & & & & + & \\
\hline $\mathrm{P} 23$ & + & + & + & + & + & + & + & + \\
\hline Gil & + & + & + & + & + & + & + & + \\
\hline Gi6 & + & + & + & + & + & + & + & + \\
\hline Gi7 & + & + & + & + & + & + & + & \\
\hline $\begin{array}{l}\text { Detection rate } \\
(\%)\end{array}$ & 94.1 & 100.0 & 100.0 & 58.8 & 58.8 & 58.8 & 100.0 & 52.9 \\
\hline
\end{tabular}

B. cereus는 자연에 널리 분포하는 포자 형성 식중독세균으 로 가열처리하여도 제거되지 않아 고춧가루, 후춧가루, 생 강가루에서 검출된 것으로 판단된다. 자외선과 적외선을
이용하여 살균을 진행하는 HACCP 인증 고춧가루 제품에 서도 B. cereus가 검출되었는데 이는 고춧가루의 자외선 및 적외선 살균이 충분히 이루어지지 않았거나 오염된 $B$. 
cereus가 포자를 형성하여 사멸되지 않은 것으로 판단된다. 따라서 고춧가루 $\mathrm{HACCP}$ 살균 공정의 보완이 필요할 것으 로 판단된다. 후춧가루, 생강가루는 모두 $\mathrm{HACCP}$ 미인증 제품으로 B. cereus를 제어할 수 있는 적절한 위생 관리 시스템의 도입과 함께 생산단계 B. cereus 오염을 관리할 수 있는 GAP 제도 도입이 필요할 것으로 판단된다.

\section{Bacillus cereus 독소 유전자 및 독소단백질}

분리 동정된 B. cereus 식중독균의 독소 유전자 특성과 독소 생산능 실험 결과는 Table 6에 나타내었다. B. cereus 17 건 모두에서 $n h e B, n h e C, e n t F M$ 독소 유전자가 검출되었 으며, 16 개(94.1\%) 균주에서 $n h e A$ 독소 유전자가 검출되었 다. $h b l C, h b l D, h b l A$ 는 각각 10 개(58.8\%) 균주에서 독소유 전자가 검출되었으며, $\mathrm{HBL}$ 독소단백질은 9 개 균주 $(52.9 \%)$ 에서 검출되었다. 검출된 B. cereus의 독소유전자를 종합해 보면 17균주 모두 한 가지 이상의 독소유전자를 가지고 있으며, 9개 균주(52.9\%)에서 $\mathrm{HBL}$ 독소단백질이 확인되어 향신료에 오염된 B. cereus에 의한 식중독 발생 가능성이 상존하는 것으로 판단된다.

B. cereus는 구토형과 설사형의 식중독을 일으키는데, 그 중 설사형 식중독은 잠복기가 8-16시간이며 B. cereus에 오염된 식품을 섭취한 후 생성된 enterotoxin에 의해 발병 한다(26). 본 실험에서 분리된 B. cereus 독소 유전자는 설사 형 식중독을 일으키는 $n h e A B C, h b l C D A$ 로 국내에서 분리된 B. cereus의 주요 독소 유전자와 일치하였다(27). HBL enterotoxin은 B. cereus의 대표적인 설사 독소로 $h b l C, h b l D$, $h b l A$ 독소 유전자로부터 생산되는 것으로 보고되고 있으며 (28), 본 실험 결과 HBL enterotoxin을 생산하는 균주는 모두 $h b l C, h b l D, h b l A$ 독소 유전자를 가지고 있는 것으로 확인되 었다. B. cereus의 설사형 식중독은 소스, 푸딩 등 단백질 식품에서 빈번하게 발생하며, 충분한 가열이 이루어지지 않은 식품을 상온에 보관할 경우 빠르게 증식하여 식중독을 일으킬 가능성이 있다(29). 향신료 가공품은 조리 시 풍미 증진을 위하여 소량 사용되나 B. cereus에 오염 된 향신료를 사용한 식품이 상온에 장시간 방치될 경우 B. cereus가 증식 하여 식중독이 발생할 가능성이 상존하는 것으로 판단되었다.

이러한 결과를 종합하여 볼 때 시중 유통되고 있는 향신 료 제품의 경우 $\mathrm{HACCP}$ 인증 여부와 관계없이 대장균군 및 B. cereus 오염도를 나타내어 향신료 재배에 GAP 제도를 도입하여 대장균군 등 미생물 오염 원인을 관리하고 기존 $\mathrm{HACCP}$ 시스템의 미생물 살균공정을 개선하여야 할 것으로 판단되었다.

\section{요 약}

본 연구에서는 대표적인 향신료가공품인 고춧가루, 후춧
가루, 생강가루, 마늘가루의 일반세균, 대장균군 및 식중독 세균 오염도를 분석하여 시중 유통 중인 향신료 제품의 미생물학적 안전성을 평가하고자 하였다. 본 실험에 사용 된 재료는 고춧가루 45 건, 후춧가루 28건, 생강가루 29건, 마늘가루 17 건, 총 119 건의 향신료를 사용하였다. 일반세 균, 대장균군 및 식중독 세균은 식품공전에 따라 실험하였 으며, B. cereus의 독소 유전자는 PCR을 이용하여 분석하였 다. 일반세균수는 $\mathrm{HACCP}$ 인증 제품에서 평균 $6.2 \pm 1.2 \mathrm{log}$ $\mathrm{CFU} / \mathrm{g}, \mathrm{HACCP}$ 미인증 제품에서 평균 $5.4 \pm 1.8 \log \mathrm{CFU} / \mathrm{g}$ 으 로 나타났다. 대장균군 오염도는 $\mathrm{HACCP}$ 인증 제품에서 $35.1 \%, \mathrm{HACCP}$ 미인증 제품에서 $32.9 \%$ 검출되어 $\mathrm{HACCP}$ 인증 제품에서 높은 오염도를 나타내었다. Salmonella spp., Listeria monocytogenes, Bacillus cereus, E. coli O157, Yersinia enterocolitica, Vibrio parahaemolyticus, Staphylococcus aureus 등 7종의 식중독균을 실험한 결과 17건의 향신료에 서 B. cereus가 검출되었다. 또한 HACCP 인증된 37건 중 7건(18.9\%), HACCP 미인증 82건 중 10건(11.8\%)에서 $B$. cereus 가 검출되었다. 본 실험결과 시중 유통되고 있는 향신 료 제품의 경우 $\mathrm{HACCP}$ 인증 여부와 관계없이 대장균군 및 B. cereus 오염도를 나타내어 향신료 재배에 농산물우수 관리 제도를 도입하여 대장균군 등 미생물 오염 원인을 관리하고 기존 $\mathrm{HACCP}$ 시스템의 미생물 살균공정 등을 개선하여야 할 것으로 판단되었다.

\section{감사의 글}

이 논문은 2018년 순천대학교 학술연구비피로 연구되었 기에 지원에 감사드립니다.

\section{References}

1. MFDS (2017) Korean food code. Ministry of Food and Drug Safety, Seoul, Korea, p 141-204

2. MAFRA (2017) Agriculture Food and Rural Affairs Statistics Yearbook. Ministry of Agriculture Food and Rural Affairs, Sejong, Korea, p 109

3. Hawer WS, Ha J, Hwang J, Nam Y (1994) Effective separation and quantitative analysis of major heat principles in red pepper by capillary gas chromatography. Food Chem, 49, 99-103

4. Kim HK, Jo KS, Park MH, Chang YS, Shin ZI (1990) Comparison of sorption characteristics of red pepper powders with their seeds mixing ratio. Korean J Food Sci Technol, 22, 817-823

5. Purseglove JW, Brown EG, Green CL, Robbins SR 
(1981) Spices. In: Pepper, Longman, NY, USA, p 10-15

6. Kim JS, Koh MS, Kim YH, Kim MK, Hong JS (1991) Volatile flavor components of Korean ginger (Zingiber officinale Roscoe). Korean J Food Sci Technol, 23, 141-149

7. Kwon SK (2003) Organosulfur compounds from Allium sativum and physiological activities. J Appl Pharmacol, $11,8-32$

8. Kim ES, Chun HJ (1993) The anticarcinogenic effect of garlic juice against DMBA induced carcinoma on the hamster buccal pouch. J Korean Soc Food Nutr, 22, 398-404

9. Ruffin J, Hunter SA (1983) An evaluation of the side effects of garlic as an antihypertensive agent. Cytobios, $37,85-89$

10. Horowitz JM (2002) 10 Food that Pack a Wallop. Time, $159,76-81$

11. Jeong CH, Shim KH, Bae YI, Choi JS (2008) Quality characteristics of wet noodle added with freeze dried garlic powder. J Korean Soc Food Sci Nutr, 37, 1369-1374

12. Korea Food and Drug Administration. http://www.mfds.go.kr/ brd/m_99/list.do (accessed August 2018)

13. Park JH, Shin JK (2016) Contamination level of commercialized pepper and sterilization effect by intense pulsed light in batch system. Korean J Food Sci Technol, 48, 525-529

14. Jeong MS, Ahn JJ, Akram K, Kim GR, Im JG, Kwon JH (2013) Microbiological and physicochemical quality characterization of commercial red pepper powders. J Food Hyg Saf, 28, 1-6

15. Jegal S, Kim JH, Joo GS, Jung SJ, Na HJ, Jo NG, Lee JM, Kim YH (2013) Survey of aflatoxin B1 and ochratoxin A on commercial dried red pepper and red pepper powder. J Food Hyg Saf, 28, 267-271

16. Park SB, Kwon SC (2015) Microbiological hazard analysis for HACCP system application to red pepper powder. KAIS, 16, 2602-2608

17. Jung JJ, Choi EJ, Lee YJ, Kang ST (2011) Effects of infrared pasteurization on quality of red pepper powder. Korean J Food Sci Technol, 43, 156-160

18. Song YJ, Park SW, Chun SC, Choi MJ, Chung KC, Lee SK (2012) Efficient treatment methods for reducing Escherichia coli populations in commercially-available red pepper powder in Korea. J Korean Soc Food Sci Nutr, 41, 875-880

19. Woo HI, Kim JB, Choi JH, Kim EH, Kim DS, Park
KS, Kim EJ, Eun JB, Om AS (2012) Evaluation of the level of microbial contamination in the manufacturing and processing company of red pepper powder. J Food Hyg Saf, 27, 427-431

20. Solberg M, Buckalew JJ, Chen CM, Schaffner DW, O'neill K, McDowell J, Post LS, Boderck M (1990) Microbiological safety assurance system for foodservice facilities. Food Technol, 44, 68-73

21. Donnelly CW, Briggs EH (1986) Psychrotropic growth and thermal inactivation of Listeria monocytogenes as a function of milk compisition. J Food Prot, 49, 994-998

22. Mok CK, Jeon HJ (2013) Low pressure discharge plasma inactivation of microorganisms in black pepper powder. Food Eng Prog, 17, 43-47

23. Lee SH, Lee HJ, Byun MW (1997) Effects of ozone treatment and gamma irradiation on the microbial decontamination and physicochemical properties of red pepper powder. J Korean Soc Food Sci Nutr, 26, 462-467

24. Kwon JH, Byun MW, Cho HO (1984) Effect of gamma irradiation on the sterilization of red pepper powder. $\mathrm{J}$ Korean Soc Food Nutr, 13, 188-192

25. Kim MH, Kim SY, Shin WS, Lee JS (2003) Antimicrobial activity of garlic juice against Escherichia coli O157:H7. Korean J Food Sci Technol, 35, 752-755

26. Kim SH, Kim MG, Kang MC, Son YW, Lee CH, Kim IB, Lee YJ, Choi SY (2004) Isolation and growth pattern of Bacillus cereus from ready-to-eat foods. J Life Sci, 14, 664-669

27. Kim JB, Kim JM, Cho SH, Oh HS, Choi NJ, Oh DH (2011) Toxin genes profiles and toxin production ability of Bacillus cereus isolated from clinical and food samples. J Food Sci, 76, 25-29

28. Kim JB, Park JS, Kim MS, Hong SC, Park JH, Oh DH (2011) Genetic diversity of emetic toxin producing Bacillus cereus Korean strains. Int J Food Microbiol, 150, 66-72

29. Cho YS, Jung EY, Lee MK, Yang CY, Shin DB (2008) Survival, isolation and characterization of Bacillus cereus from Sunshik J Food Hyg Saf, 23, 343-347

30. Ngamwongsatit $P$, Buasri W, Pianariyanon P, Pulsrikan C, Ohba M, Assavanig A, Panbabgred W (2008) Broad distribution of enterotoxin genes ( $h b l C D A$, nhe $A B C$, cytK, and entFM) among Bacillus thuringiensis and Bacillus cereus as shown by novel primers. Int J Food Microbiol, 121, 352-356

31. Yang IC, Shih DH, Huang TP, Huang YP, Wang JY, Pan TM (2005) Establishment of a novel multiplex PCR 
assay and detection of toxigenic strains of the species in the Bacillus cereus group. J Food Prot, 68, 2123-2130

32. Ghelardi E, Celandroni F, Salvetti S, Barsotti C, Baggiani A, Senesi S (2002) Identification and characterization of toxigenic Bacillus cereus isolates responsible for two food-poisoning outbreaks. FEMS Microbiol Lett, 208, 129-134 